\title{
Effects of nano, chelated and conventional iron as soil addition on growth, anatomy and early yield of cucumber plants (cucumus sativus $l$ ).
}

\author{
El-Desoukey, Heba ${ }^{1}$, S.;Abd-El-Dayem ${ }^{1}$, H.M; Islam² ${ }^{2}$ R.K; Harker,T² ${ }^{3}$ Gao, G ${ }^{3}$; Bergefurd, B. ${ }^{3}$;.Ismail, Faten, ${ }^{1}$ \\ H. and $\mathrm{Mady}^{1}$, M. A. \\ 1-Botany Department Faculty of Agric. Benha Univ. Egypt, 2- Soil, Water and Bioenergy Resources \\ Department, Ohio State University South Centers, Piketon, OH, USA. 3- Horticulture Department, Ohio \\ State University South centers, Piketon, OH, USA. \\ Corresponding author: heba.alabd@fagr.bu.edu.eg
}

\begin{abstract}
Two greenhouse experiments in Randomized complete block design with four replications were conducted at Soil, Water and Bioenergy Resources, South Centers, Piketon, OH, Ohio State University, USA, to study the effect of iron forms (conventional Ferric chloride $\left(\mathrm{FeCl}_{3-} 6 \mathrm{H}_{2} \mathrm{O}\right)$, chelated iron $(6 \% \mathrm{Fe})$ and Nano Iron Oxide $\left(\mathrm{Fe}_{2} \mathrm{O}_{3}\right.$, alpha, $99 \%$, )at different doses $\left(0,50\right.$ and $100 \mathrm{mg} / \mathrm{kg}^{-1}$ soil $)$ on growth, anatomy and early yield in cucumber plants (Cucumus sativusL.) cv.(Tyria F1) during 2015 and 2016 seasons. Results showed that, the different applied treatments increased plant height, leaf number, leaf area (LA) $\left(\mathrm{cm}^{2}\right)$, fresh weight and dry weight at60 and 90 days after transplanting during the both seasons of cultivation. Also, anatomical studies were carried out on stems i.e.(stem thickness, xylem and Phloem thickness, and numbers, cambium region thickness, Fiber tissue thickness and pith thickness) and leaves measurements i.e.(plaside and spongy tissue and xylem thickness, number of vessels and phloem at 30 days of plant age in the second season. Data showed positive response to the different applied treatments especially with nano iron at $100 \mathrm{mg} / \mathrm{kg}^{-1}$.In addition, early fruits number/plant, fruit length, fruit diameterand earlyfruit weight per plant increased due to the different applied treatments in the first and second seasons. Results also, showed that soil application of nano iron at $100 \mathrm{mg} / \mathrm{kg}^{-1}$ is the most effective treatment in this respect compared with other tested iron sources and control treatments.
\end{abstract}

Keywords: nano ferric, chelated, growth, early yield, anatomy.

\section{Introduction}

With the development of nanotechnology, nanomaterials are being used in the field of agriculture (Li et al.,2014). Nanomaterials consist of nanometerscale particles with a very small diameter and a large specific surface area. In comparison with traditional materials; nanomaterials have many special functions resulting from the quantum size effect, microscopic quantum tunneling, and dielectric confinement effect (Michal et al.,2005; Hochella et al.,2008), and also have some new functions (Gui et al.,2015). Consequently, such nanomaterials have many potential applications. . In September 2003, the United States Department of Agriculture stated the importance of using nanotechnology in agricultural production; since then, many other countries have increased research efforts in this field (Sanguansri and Augustin, 2006). In addition, many experts have proposed that nanoparticles should be used in the field of soil-plant nutrition to achieve sustainable development of agricultural production with minimal environmental impacts (Sastry et al., 2007). Nowadays, nanotechnology considered a new technical revolution. Therefore, nanomaterials will become the new materials for agricultural development, and represent new ideas and directions for global agricultural production (Chen and Yada, 2011). Iron $(\mathrm{Fe})$ is an essential nutrient for all organisms (Zuo and Zhang, 2011) and its deficiency is widespread among many different crops (SánchezAlcalá et al., 2014). Despite of Fe content in soil is usually high, but a large proportion is being fixed to soil particles (Mimmo et al.,2014; Bindraban et al.,2015). Also, $\mathrm{Fe}$ is mainly in the form of insoluble $\mathrm{Fe} 3+$, especially in high-pH and aerobic soils; therefore, these soils are usually deficient in the available form of $\mathrm{Fe} 2+$. Because plants usually absorb $\mathrm{Fe} 2+$ from soil, Fe-deficient soils lead to Fe-deficient plants (Kobayashi and Nishizawa, 2012). In plants, Fe participates in many physiological processes including chlorophyll biosynthesis, respiration, and redox reactions. Hence, iron fills many essential roles in plant growth and development, including chlorophyll synthesis, thylakoid synthesis and chloroplast development (Miller et al.,1995).(Mimmo et al.,2014; Ye et al.,2015; Zargar et al.,2015). In this respect, since. Iron (Fe) is a cofactor for approximately 140 enzymes that catalyze unique biochemical reactions (Brittenham, 1994). Iron is required at several steps in the biosynthetic pathways., Fe deficiency not only affects the growth and development of plants, but can also lead to anemia in animals and humans (Li et al., 2014). Therefore, it is important to improve the utilization efficiency of Fe fertilizers. The idea is quite simple: nanodevices can help to deliver the nutrients in the right place at the right time and to reduce the action of external agents leading to losses by degradation, etc. The expected effect should be a reduction in the amount of active chemicals incorporated into the plants and soils leading to a reduced negative impact on the environment. However, many researches and knowledge are needed 
to accomplish those goals not only for the development and synthesis of nano carriers and nano materials, but also for studying the interactions of such nano devices with the plants and the environment. Indeed, it is necessary to study how plants absorb and uptake nanoparticles, how they move inside the plant, and how they interact with the plant cell. Cucumber is one of the vegetable crops which is very important for the human nutrition and human health due to its high content from fiber, minerals and many other compounds. Foliar application of chelated iron increased vegetative and reproductive growth and fruit quality of cucumber plants(Mohsen 2013). Nano fertilizer has a positive effect on spinach wet weight by increasing growth indexes such as leaf area index, crop growth rate and leaf numbers of treated plants based on the same effect of different nano fertilizer concentrations (Alirezaladanet al., 2012). reported that the epidermis cells of the control were similar in shape and size, while the epidermal cells of the NPtreated leaves became larger in size and reached a maximum size when $3 \mathrm{mg} / \mathrm{kg}^{-1} \mathrm{Fe}_{3} \mathrm{O}_{4}$ nano Particles NPS foliar spray was used. In addition, the thickness of mesophyll tissue, which is specialized photosynthetic tissue that contains chloroplasts in palisade and spongy parenchyma tissue, was greater in $\mathrm{Fe}_{3} \mathrm{O}_{4}$ treated leaves compared to control leaves. The leaf spray treatment was also more effective than soil treatment, and the air spaces were largest in foliar sprayed leaves. Therefore, foliar spray was the most effective treatment, followed by soil treatment, compared to control leaves. This finding was clear based on the chlorophyll concentration, which was higher in leaves receiving the foliar treatment compared to soil treatment. Therefore, this study aimed to evaluate the effect of different doses of Nanoiron as soil addition on growth, growth performance, anatomical structure of (stem and leaf)and early fruits yield in cucumber plants in comparison with other iron forms i.e., conventional or chelated ones.

\section{Materials and Methods}

Two greenhouse experiments in randomized complete block design (RCBD) with four replications were conducted at Soil, Water and Bioenergy Resources, South Centers, Piketon, OH, Ohio State University, USA to study the effect of iron sources conventional ferric chloride $\left(\mathrm{FeCl}_{3-} 6 \mathrm{H}_{2} \mathrm{O}\right)$, chelated iron $(6 \% \mathrm{Fe})$ and nano Iron oxide $\left(\mathrm{Fe}_{2} \mathrm{O}_{3}\right.$, alpha, $99 \%$, $30-100 \mathrm{~nm})$ at doses of 0,50 and $100 \mathrm{mg} / \mathrm{kg}^{-1}$ soil on growth, anatomical structure and fruit yield of cucumber, (Cucumus sativusL.)(Tyria F1) during 2015-2016 and 2016-2017 seasons.Seeds of cucumber cv,(Tyria F1) (Cucumus sativusL.) imported from LTD. USA company. the seeds were sowing in October $6^{\text {th }}$ cucumber seeds were planted respectively in the growth chamber and were moved from the growth chamber to the green house on November $13^{\text {th }}$ cucumber seedlings were transplanted to the greenhouse in plastic bags $(30 \mathrm{~cm})$ the bags size $12 \mathrm{lb}$ $(5.44 \mathrm{~kg})$ of soil media promixpx ingredients (Canadian sphagnum peat moss $(75-85 \%)$, perlite horticulture grade, vermiculite horticulture grade, dolomitic and cacitic limestone (PH adjuster) wetting agent, starter nutrient. Imported from premier tech horticulture INC.127 South $5^{\text {th }}$ street, suite 300 Quaketown, BA USA. 18951.

All the different designed treatments were added to the soil after 10 days from transplanting in both the first and second seasons. All recommended agricultural managements through plant growth and development were applied in both seasons.

The characteristics of both the irrigation water quality and growing media are presented in Table1.

Table 1. Main characteristics of the Water used for irrigation and plant growth media.

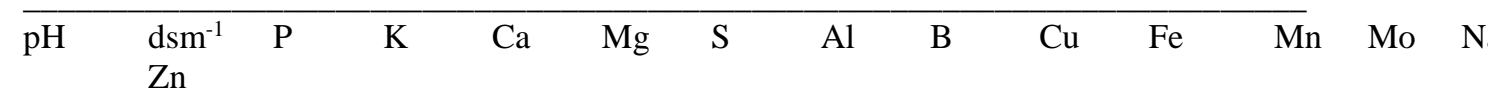

\begin{tabular}{|c|c|c|c|c|c|c|c|c|c|c|c|c|c|}
\hline \multirow[b]{2}{*}{7.3} & \multirow[b]{2}{*}{0.71} & \multirow[b]{2}{*}{6.5} & \multirow[b]{2}{*}{36} & \multicolumn{8}{|c|}{ Elemental composition of the irrigation water (mg/l) } & \multirow[b]{2}{*}{0.3} & \multirow[b]{2}{*}{12} \\
\hline & & & & 208 & 24 & 20 & 13 & 0.2 & 1.6 & 7.7 & 1 & & \\
\hline & & & & El & & & & & & & & & \\
\hline 4.7 & 0.8 & 118 & 617 & 112 & 31 & 84 & 6 & 3.2 & 1.5 & 2.5 & 3. & 0.3 & 43 \\
\hline
\end{tabular}

\section{Iron Sources:}

Conventional Fe fertilizer $\left(\mathrm{FeCl}_{3}-6 \mathrm{H} 2 \mathrm{O}\right)$ :

Ferric chloride certified A.C.S. (Lump) $\mathrm{FeCl}_{3}-6$

H2O F.W. 270.32 limit about $0.002 \%$ P T. imported from Fisher Scientific Company.

\section{Chelated Iron:}

EDDHA Chelated Iron 6\%: EthylenediamineN,N'-bis (2-hydroxyphenylacetic acid) imported from Grow More Company.

\section{Nano iron:}

Nano iron imported from Nanostructured \& Amorphous Materials, Inc.

16840 Clay Road, Suite \#113, Houston, TX 77084, USA 


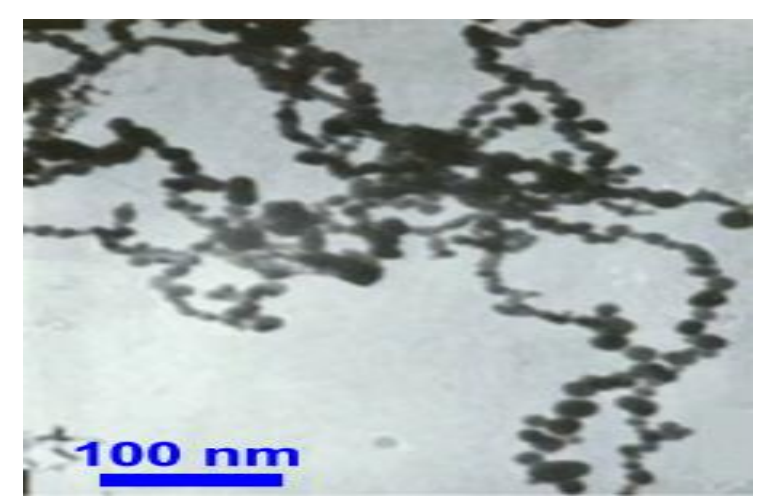

Fig (1) Nano particlesCharacteristics under electronic microscope from Nano structured \& Amorphous Materials, Inc. Company.

All iron sources at different doses were added to the soil one time after 10days from transplanting during 2015 and 2016 seasons.

\section{Data Recorded}

\section{I- Morphological growth measurements:}

Different morphological characteristics of cucumber plants were measured at 60 and 90 days after transplanting. These characteristics involved: Plant height $(\mathrm{cm})$, number of leaves / plant, shoot fresh weight and dry weight $(\mathrm{g}) /$ plant and total leaf area /plant $\left(\mathrm{cm}^{2}\right)$ using Handheld Laser Leaf Area Meter imported from CID Bio-Science,Inc,1554 NE 3rd Avenue Camas, WA USA 98607.The samples of each treatment were dried in oven at $65{ }^{\circ} \mathrm{C}$ for 48 hours to take the dry weight .

\section{II- Anatomical studies:}

At 30 days after transplanting in the second growing season specimens of stem and leaf were taken from the $2^{\text {nd }}$ apical internode of the stem and from the second apical leaf. Those vegetative specimens were killed and fixed in F.A.A. according to (Sass, 1951). The selected materials were washed in $50 \%$ ethyl alcohol, dehydrated in a normal butyl alchohol series, embedded in paraffin wax of melting point $56^{\circ} \mathrm{C}$, section to thickness of 20 micrometer $(\mu \mathrm{m})$, double stained with saffarine and fast green, cleared in xylene and mounted in Canada balsam (Nassar and El-Sahhar, 1998). Four section treatments were microscopically inspected to detect histological manifestations of noticeable responses resulted from treatments. Count and measure $(\mu)$ were taken using a micrometer eye piece.

\section{III-Early Yield and Yield components:}

From the harvesting start until reachthree weeks the early yield per plant was calculated ( $\mathrm{kg} /$ plant),fruit length $(\mathrm{cm})$, fruit diameter $\left(\mathrm{cm}^{2)}\right)$ and fruits number/plant were measured at the same time.

\section{Statistical analysis:}

Statistical analysis was performed using SAS 9.3 (SAS 2010). Different iron forms were considered as fixed effects. F-protected simple and interactive treatment means were separated by the Tukey's significant difference test, when the ANOVA showed significant effects $(\mathrm{p} \leq 0.05)$ of predictor variables on dependent variables, with a value of $p<0.05$ unless otherwise mentioned. Regression and correlation analyses were performed by using SigmaPlot ${ }^{\circledR}$ software.

\section{Results \& Discussions \\ Vegetative Growth parameters:}

Data in Table (2) indicates that the different iron forms i.e. the conventional, chelated and nano iron at the different doses 0,50 and $100 \mathrm{mg} / \mathrm{kg}^{-1}$ significantly increased growth parameters i.e., plant height, leaves numbers, leaf area $\mathrm{cm}^{2} /$ plant (LA) at 60 and 90 days after transplanting compared with thecontrol during 2015 and 2016 seasons. The most effective treatment among these iron forms is nano at $100 \mathrm{mg} / \mathrm{kg}^{-1}$ during 2015 and 2016 seasonsat the aforementioned different times.

These results are in agreement with those of Mohamed et al.,(2014) reported that foliar application of wheat plant with nano iron at 0.2.4 and $6 \mathrm{~g} / \mathrm{l}$ ) increased plant height, tillers numbers and number of leaves/plant.

Abo-Sedera et al.,(2016) on snap bean and Abou-Shlell (2017) on moringa plants reported that foliar application withLithovit $(\mathrm{Ca}, \mathrm{Mg}$ and $\mathrm{Fe}$ nano particles) increased plant height, No. of leaves /plant, No. of branches /plant, fresh and dry weight/ plant and leaf area /plant. Jayvanth et al.,(2017) found that foliar application of strawberry plants with iron oxide nano particles at $150 \mathrm{mg} / \mathrm{l}^{-1}$ increased plant height, number of leaves and petiole length.,

Data in Table (3) show that nano iron at $100 \mathrm{mg} / \mathrm{kg}^{-1}$ was the most effective treatment on fresh weight and dry weight at 60 and 90 days after transplanting (DAT) during 2015 and 2016 seasons. In context the different applied treatments of iron sources (conventional at 50 and 100, chelated at 50 and 100 and nano at 50 and $100 \mathrm{mg} / \mathrm{kg}^{-1}$ ) significantly increased the same characteristics at 60 and 90 days after transplanting during 2015 and 2016 seasons. The application of $\mathrm{Fe}$ shown significant positive effects, in most cases, on growth measurements and chemical composition of cumin and soybean (Kobayashi and Nishizawa, 2012). 
Table 2. Effect of Nano, Chelated and Conventional iron on plant height, $(\mathrm{cm})$, leaves number and leaf area $\left(\mathrm{cm}^{2}\right)$ of $\mathrm{cucumber}$ plants at 60 and 90 days after transplanting during 2015 and 2016 seasons.

\section{Charactractics}

Treatments

\section{After 60 days $\quad$ After 90 days}

\begin{tabular}{|c|c|c|c|c|c|c|c|c|c|c|c|c|c|}
\hline \multirow{2}{*}{$\begin{array}{c}\text { Iron } \\
\text { Source }\end{array}$} & \multirow{2}{*}{$\begin{array}{l}\text { Dose } \\
\mathrm{mg} / \mathrm{kg}^{-1}\end{array}$} & \multicolumn{2}{|c|}{ Plant Height (cm) } & \multicolumn{2}{|c|}{ Leaves Number/plant } & \multicolumn{2}{|c|}{ Leaf Area $\left(\mathrm{cm}^{2}\right)$} & \multicolumn{2}{|c|}{ Plant Height (cm) } & \multicolumn{2}{|c|}{ Leaves Number/plant } & \multicolumn{2}{|c|}{ Leaf Area $\left(\mathrm{cm}^{2}\right)$} \\
\hline & & $\begin{array}{c}1^{\text {st }} \\
\text { Season }\end{array}$ & $\begin{array}{c}2^{\text {nd }} \\
\text { Season }\end{array}$ & $\begin{array}{c}1^{\text {st }} \\
\text { Season }\end{array}$ & $\begin{array}{c}2^{\text {nd }} \\
\text { Season }\end{array}$ & $\begin{array}{c}1^{\text {st }} \\
\text { Season }\end{array}$ & $\begin{array}{c}2^{\text {nd }} \\
\text { Season }\end{array}$ & $\begin{array}{c}1^{\text {st }} \\
\text { Season }\end{array}$ & $\begin{array}{c}2^{\text {nd }} \\
\text { Season }\end{array}$ & $\begin{array}{c}1^{\text {st }} \\
\text { Season }\end{array}$ & $\begin{array}{c}2^{\text {nd }} \\
\text { Season }\end{array}$ & $\begin{array}{c}1^{\text {st }} \\
\text { Season }\end{array}$ & $\begin{array}{c}2^{\text {nd }} \\
\text { Season }\end{array}$ \\
\hline CONVFe & & $206.7 b$ & $195.2 \mathrm{c}$ & $27.4 \mathrm{c}$ & $30.9 c$ & $2461.4 \mathrm{c}$ & $2393.2 c$ & $233.2 b$ & $229.1 c$ & $35.9 a$ & $37.5 \mathrm{c}$ & $2743.1 \mathrm{c}$ & $2733.2 \mathrm{c}$ \\
\hline CHELFe & & $206.8 b$ & $197.8 \mathrm{~b}$ & $28.2 b$ & $34.1 \mathrm{~b}$ & $2841.7 b$ & $2664.9 b$ & $233.6 b$ & $232.4 \mathrm{~b}$ & $36.0 \mathrm{a}$ & $39.0 \mathrm{~b}$ & $3037.5 b$ & $3103.9 b$ \\
\hline NANOFe & & $214.9 a$ & $202.0 \mathrm{a}$ & $28.3 \mathrm{a}$ & $35.1 \mathrm{a}$ & $2677.8 \mathrm{a}$ & $2839.5 a$ & $238.5 \mathrm{a}$ & $237.4 \mathrm{a}$ & $36.3 a$ & $41.9 a$ & $3760.3 a$ & $3750.2 \mathrm{a}$ \\
\hline & $\mathbf{0}$ & $205.5 y$ & $192.1 z$ & $27.7 \mathrm{z}$ & $29.7 z$ & $2326.7 z$ & $2258.5 z$ & $231.2 \mathrm{y}$ & $227.8 z$ & $32.0 \mathrm{z}$ & $35.6 \mathrm{z}$ & $2619.4 z$ & $2567.7 \mathrm{z}$ \\
\hline & 50 & $212.8 \mathrm{x}$ & $200.9 y$ & $27.9 y$ & $34.8 \mathrm{y}$ & $2798.8 \mathrm{y}$ & $2766.9 y$ & $234.1 x$ & $233.1 \mathrm{y}$ & $36.7 y$ & $41.3 y$ & $3423.6 y$ & $3403.4 y$ \\
\hline & 100 & $210.1 x$ & $202.0 x$ & $28.3 x$ & $35.7 x$ & $2855.3 x$ & $2872.2 \mathrm{x}$ & $240.1 x$ & $237.9 x$ & $39.5 x$ & $41.5 x$ & $3497.9 x$ & $3616.1 x$ \\
\hline & \multicolumn{13}{|c|}{ Source $x$ Dose } \\
\hline CONVFe & 0 & 204.2 & 193.4 & 27.3 & 29.0 & 2179.6 & 2186.3 & 230.8 & 227.5 & 32.5 & 36.3 & 2424.8 & 2412.5 \\
\hline & 50 & 207.1 & 194.1 & 27.0 & 32.0 & 2513.2 & 2436.3 & 235.2 & 228.0 & 37.0 & 38.3 & 2848.8 & 2820.5 \\
\hline & 100 & 208.7 & 198.2 & 28.0 & 31.8 & 2691.3 & 2557.0 & 233.7 & 231.9 & 38.3 & 38.0 & 2955.8 & 2966.5 \\
\hline CHELFe & 0 & $206.3^{\mathrm{ns}}$ & $191.1^{*}$ & $28.3^{\mathrm{ns}}$ & $29.8^{*}$ & $2434.4^{*}$ & $2259.1^{*}$ & $231.1^{\mathrm{ns}}$ & $228.5^{*}$ & $32.8^{\mathrm{ns}}$ & $34.5^{*}$ & $2698.5^{*}$ & $2609.7^{*}$ \\
\hline & 50 & 208.0 & 202.5 & 28.8 & 35.8 & 3033.6 & 2805.9 & 230.7 & 232.3 & 36.5 & 41.5 & 3269.9 & 3309.6 \\
\hline & 100 & 206.2 & 199.8 & 27.5 & 36.8 & 3057.0 & 2929.6 & 239.1 & 236.3 & 38.8 & 41.0 & 3144.2 & 3392.4 \\
\hline NANOFe & $\mathbf{0}$ & 205.9 & 191.7 & 27.5 & 30.3 & 2366.0 & 2329.9 & 231.6 & 227.6 & 30.8 & 36.0 & 2734.9 & 2681.0 \\
\hline & 50 & 223.3 & 206.1 & 28.0 & 36.5 & 2849.6 & 3058.6 & 236.3 & 239.1 & 36.5 & 44.3 & 4152.2 & 4080.1 \\
\hline & 100 & 215.5 & 208.1 & 29.3 & 38.5 & 2817.8 & 3130.1 & 247.5 & 245.6 & 41.5 & 45.5 & 4393.8 & 4489.4 \\
\hline
\end{tabular}

* indicates significant interaction among iron source $\mathrm{x}$ dose over time at $\mathrm{p}<0.05$.

$¥$ Means separated by same lower case letters in each column is not significantly different among iron sources at $\mathrm{p}<0.05$.

$€$ Means separated by same lower case letters in each column is not significantly different among iron doses at $\mathrm{p}<0.05$.

ns means Non-Significant. 
Table 3. Effect of nano, chelated and conventional iron on shoot fresh and dry weight ( $\mathrm{g}$ ) of cucumber plants(Cucumus satives L.) at 60 and 90 days after transplanting during 2015 and 2016 seasons.

\section{Characteristics}

After 60 days

\section{Treatments}

Iron Source

Dose $\mathrm{mg} / \mathrm{kg}^{-1}$

\section{resh weight $(\mathrm{g}) / \mathrm{plant}$}

$\begin{array}{cc}1^{\text {st }} & 2^{\text {nd }} \\ \text { season } & \text { season }\end{array}$

CONVFe

CHELFe

NANOFe

$1190 \mathrm{~b} \quad 1141 \mathrm{c}$

$1200 \mathrm{~b}$

$1141 \mathrm{c}$

$1249 \mathrm{a}$

$$
1198 b
$$

$1269 a$

$\begin{array}{cc}\text { Dry weight }(\mathrm{g}) / \text { plant } \\ 1^{\text {st }} & 2^{\text {nd }} \\ \text { season } & \text { season }\end{array}$

$169 \mathrm{c} \quad 162 \mathrm{c}$

$201 b$

$198 b$

$271 \mathrm{a}$

$252 \mathrm{a}$

Sea

\section{Fresh weight (g)/plant

$\begin{array}{cc}1^{\text {st }} & 2^{\text {nd }} \\ \text { Season } & \text { season }\end{array}$

Dry weight (g)/ plant

$1^{\text {st }} 2^{\text {nd }}$

1629b season season

$1651 \mathrm{~b}$

$248 \mathrm{c}$

$249 c$

$1651 \mathrm{~b} \quad 1643 \mathrm{~b}$

$256 b$

$251 b$

$1779 \mathrm{a}$

$1775 \mathrm{a}$

$358 \mathrm{a}$

$305 \mathrm{a}$

\begin{tabular}{|c|c|c|c|c|c|c|c|c|c|}
\hline & $\mathbf{0}$ & $1071 \mathrm{z}$ & $1064 z$ & $168 \mathrm{z}$ & $148 z$ & $1538 z$ & $1515 z$ & $217 z$ & $224 z$ \\
\hline & 50 & $1243 y$ & $1257 y$ & $228 y$ & $224 y$ & $1736 y$ & $1723 y$ & $277 y$ & $288 y$ \\
\hline & 100 & $1325 x$ & $1287 x$ & $243 x$ & $243 x$ & $1784 \mathrm{x}$ & $1787 \mathrm{x}$ & $367 x$ & $293 x$ \\
\hline \multicolumn{10}{|c|}{ Source X Dose } \\
\hline \multirow[t]{3}{*}{ CONVFe } & $\mathbf{0}$ & 1091 & 1075 & 157 & 143 & 1602 & 1539 & 232 & 234 \\
\hline & 50 & 1153 & 1195 & 179 & 176 & 1627 & 1623 & 255 & 263 \\
\hline & 100 & 1325 & 1154 & 171 & 169 & 1657 & 1660 & 257 & 252 \\
\hline \multirow[t]{3}{*}{ CHELFe } & $\mathbf{0}$ & $1071 *$ & $1066^{*}$ & $180 *$ & $156^{*}$ & $1508^{*}$ & $1507 *$ & $210^{*}$ & $217 *$ \\
\hline & 50 & 1262 & 1263 & 199 & 198 & 1677 & 1652 & 271 & 270 \\
\hline & 100 & 1267 & 1264 & 215 & 250 & 1769 & 1770 & 286 & 267 \\
\hline \multirow[t]{3}{*}{ NANOFe } & $\mathbf{0}$ & 1051 & 1049 & 166 & 147 & 1504 & 1500 & 209 & 221 \\
\hline & 50 & 1314 & 1314 & 305 & 299 & 1905 & 1895 & 306 & 332 \\
\hline & 100 & 1382 & 1445 & 343 & 310 & 1927 & 1931 & 558 & 361 \\
\hline
\end{tabular}

* indicates significant interaction among iron source $\mathrm{x}$ dose over time at $\mathrm{p}<0.05$.

$¥$ Means separated by same lower case letters in each column is not significantly different among iron sources at $p<0.05$.

$€$ Means separated by same lower case letters in each column is not significantly different among iron doses at $\mathrm{p}<0.05$. 


\section{II- Anatomical studies: 1-Stem anatomy}

Data in Table (4) and Fig (2) indicate that stem diameter, fibers thickness and number, Cambial region thickness, phloem thickness upper and outer, xylem thickness, numberof rows and vessel diameterare increased due to application of iron forms at different doses compared with the control in cucumber plants. The highest valueswere achieved due toapplication of nano iron source at $100 \mathrm{mg} / \mathrm{kg}^{-1}$ dose in different traits. Meanwhile, control treatment gave the lowest value in different stem anatomy parameters. The increase existed in stem diameter with different applied iron forms were preceded with obvious increases in the phloem units that well help the plant to translocate more photosynthates production from sources (leaves and stem) to fruits, thereby, increased in fruits size and number per plant (Table 6).

\section{2-Leaf anatomy}

Data in Table (5)and Fig (3) indicate that different iron applied treatments i.e. conventional at $50,100 \mathrm{mg} / \mathrm{kg}^{-1}$, chelated at 50 and $100 \mathrm{mg} / \mathrm{kg}^{-1}$ and nano at 50 and $100 \mathrm{mg} / \mathrm{kg}^{-1}$ increased thickness of leaf midrib, length of large vascular bundle, width of large midrib in the vascular bundle, , phlome thickness, (upper\&lower), xylem thickness, and rows number, vessel diameter, plaside and spongy tissue thickness compared with the control treatments in cucumber leaf at 30 days after transplanting in second season.

The increases of the anatomy measurements could be attributed to the beneficial effects of nano iron on increasing the different structures of leaf tissue during plant growth and development, i.e. palisade and spongy tissue thickness, outer and inner phloem, different xylem parts (thickness, numbers and size). The increment of the conductive tissues (xylem \&phloem) are also of a great importance because they could be also involved in the interpretation about why vigorous growth and high yielded fruits were existed with different applied treatments specially in case of nano iron at $100 \mathrm{mg} / \mathrm{kg}^{-1}$. The positive alterations in cucumber stem \&leaf anatomy treated with different treatments led to vigorous growth and enhancement of flowering and fruit setting of treated plants. Also, it could be noticed that the increases in stem \&leaf anatomy measurements were completely reversed upon vegetative and reproductive growth of treated plants. So the, present study revealed increases of xylem tissue, i.e. the route of mineral nutrients and water translocation from roots to leaves and the phloem tissue (outer and inner) i.e., the pathway of different assimilates from leaves to fruits and different sinks in cucumber plants., thereby, improvements of translocation events directly could be considered as a direct reason for increment the final fruit yield.
In general, the stimulatory effects of applied iron forms on the anatomy features of treated plants could be attributed to the effect cambium activity. The increment of cambium activity could mainly attributed to the increase of endogenous hormones level especially cytokinins and auxins, (Sotiropoulos et al.,2002), thereby the plant yield and yield component will increase (Tabe 6).

These results are in agreement withAgamy (2004)onfennel plants and Abbas (2013) on dill plants, showed that all rates of foliar application of $\mathrm{Fe}$ at $0,50,100$ and $150 \mathrm{mg} / \mathrm{l}$ significantly increased cortex, thickness, number and thickness of vascular bundles and vascular units (diameter of stem) while pith thickness decreased with the same foliar application. Abou-Shlell (2017) reported that foliar application of moringa plants with Lithovit( nano particles) at $500 \mathrm{mg} / \mathrm{l}$ increased anatomical measurements in stem and leaf i.e. stem diameter, phloem and xylem thickness and vessel diameter.

\section{III- Early yield and its components (quality)}

The results in Table (6) and Fig (2) indicate that fruit number/plant, fruit length $(\mathrm{cm})$ and fruit early yield $\mathrm{kg} /$ plant significantly increased with application of nano iron at $100 \mathrm{mg} / \mathrm{kg}^{-1}$ by 1.5 to 3 times over the control during 2015 and 2016 seasons. While conventional and chelated forms of iron at 50 and $100 \mathrm{mg} / \mathrm{kg}^{-1}$ increased fruit number /plant, fruit length $(\mathrm{cm})$ and fruit yield $\mathrm{kg} / \mathrm{plant}$ during first and second seasons.

Early fruit number and yield /plant were in parallel to the applied dose of each iron source. Also, the highest early fruit yield /plant was existed with nano iron at $100 \mathrm{mg} / \mathrm{kg}^{-1}(8.51 \mathrm{~kg})$ followed by chelated at $100 \mathrm{mg} / \mathrm{kg}^{-1}(5.45 \mathrm{~kg})$ and conventional at $100 \mathrm{mg} / \mathrm{kg}^{-1}(4.11 \mathrm{~kg})$, while the control value was $(3.29 \mathrm{~kg})$, during first season. Shankramma et al., (2016) reported that soil addition of nano iron improve tomato yield and quality.

In this respect the obtained increases in cucumber fruit number, length and cucumber yield it augmented plants ability to harvest more light energy by delivering carbon nanotubes into chloroplast, and also carbon nanotubes could serve as artificial antennae that allow chloroplast to capture wavelengths of light which is not in their normal range, such as ultraviolet, green, and nearinfrared(Cossins 2014). Also, increased in plant growth measurements (Table 2) and biomass production (Table 3), thereby increased cucumber fruits number and size and cucumber yield production and quality. 
Table 4. Effect of nano, chelated and conventional iron on stem anatomy measurements microns ( $\mu$ )of cucumber plants at 30 days after transplanting in the second cultivation season.

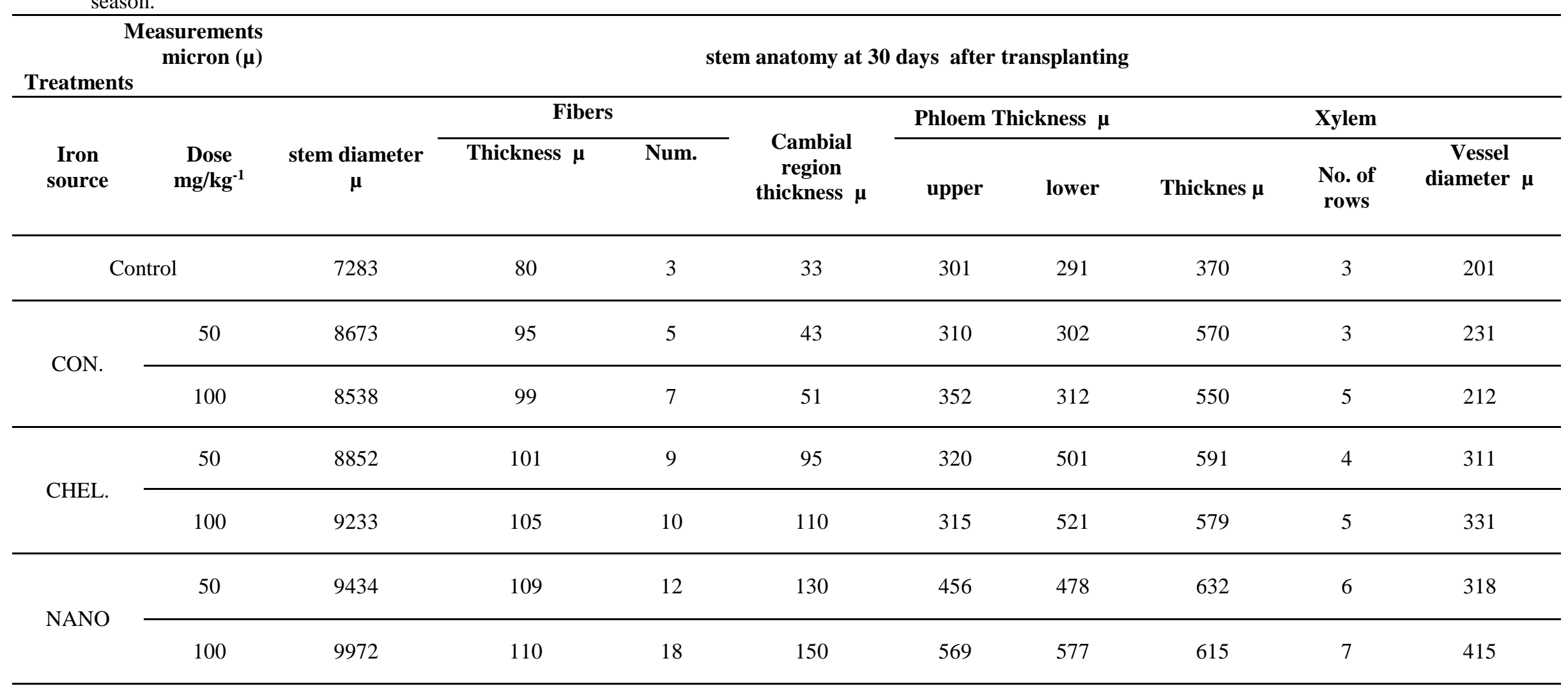


Table 5. Effect of nano, chelated and conventional iron on leaf anatomy measurements micron $(\mu)$ of cucumber plantsat 30 days after transplanting during the second cultivation season.

\begin{tabular}{|c|c|c|c|c|c|c|c|c|c|c|c|}
\hline \multicolumn{2}{|r|}{$\begin{array}{r}\text { easurements } \\
\text { micron }(\boldsymbol{\mu})\end{array}$} & \multirow{2}{*}{$\begin{array}{l}\text { Thickness } \\
\text { of leaf } \\
\text { midrib }(\mu)\end{array}$} & \multirow{2}{*}{$\begin{array}{c}\text { Length } \\
\text { of large } \\
\text { midrib } \\
\text { vascular } \\
\text { bundle } \\
(\mu)\end{array}$} & \multirow{2}{*}{$\begin{array}{c}\text { Width of } \\
\text { large } \\
\text { midrib } \\
\text { vascular } \\
\text { bundle }(\mu)\end{array}$} & \multicolumn{2}{|c|}{ Phloem thickness. $(\boldsymbol{\mu})$} & \multicolumn{3}{|c|}{ Xylem tissue } & \multirow{2}{*}{$\begin{array}{c}\text { Plaside } \\
\text { tissue } \\
\text { thick. }(\mu)\end{array}$} & \multirow{2}{*}{$\begin{array}{c}\text { Spongy } \\
\text { Tissue } \\
\text { thick. }(\boldsymbol{\mu})\end{array}$} \\
\hline $\begin{array}{l}\text { Iron } \\
\text { Source } \\
\end{array}$ & $\begin{array}{l}\text { Dose } \\
\mathrm{mg} / \mathrm{kg}^{-1} \\
\end{array}$ & & & & upper & lower & $\begin{array}{c}\text { Xylem tissue } \\
\text { thick }(\mu)\end{array}$ & $\begin{array}{c}\text { No. of } \\
\text { xylem rows } \\
\end{array}$ & $\begin{array}{c}\text { Vessel } \\
\text { diameter }(\mu)\end{array}$ & & \\
\hline \multicolumn{2}{|c|}{ Control } & 2780 & 752 & 315 & 310 & 131 & 310 & 4 & 74 & 112 & 236 \\
\hline \multirow{2}{*}{ CONV. } & 50 & 2876 & 835 & 366 & 280 & 205 & 350 & 5 & 91 & 115 & 315 \\
\hline & 100 & 3054 & 982 & 387 & 333 & 215 & 434 & 5 & 112 & 136 & 320 \\
\hline \multirow{2}{*}{ CHEL. } & 50 & 3125 & 1140 & 395 & 363 & 324 & 453 & 6 & 123 & 158 & 341 \\
\hline & 100 & 3168 & 1194 & 412 & 351 & 330 & 513 & 6 & 162 & 178 & 381 \\
\hline \multirow{2}{*}{ Nano } & 50 & 3289 & 1287 & 455 & 372 & 352 & 563 & 6 & 168 & 189 & 410 \\
\hline & 100 & 3470 & 1388 & 562 & 415 & 391 & 582 & 7 & 192 & 226 & 439 \\
\hline
\end{tabular}




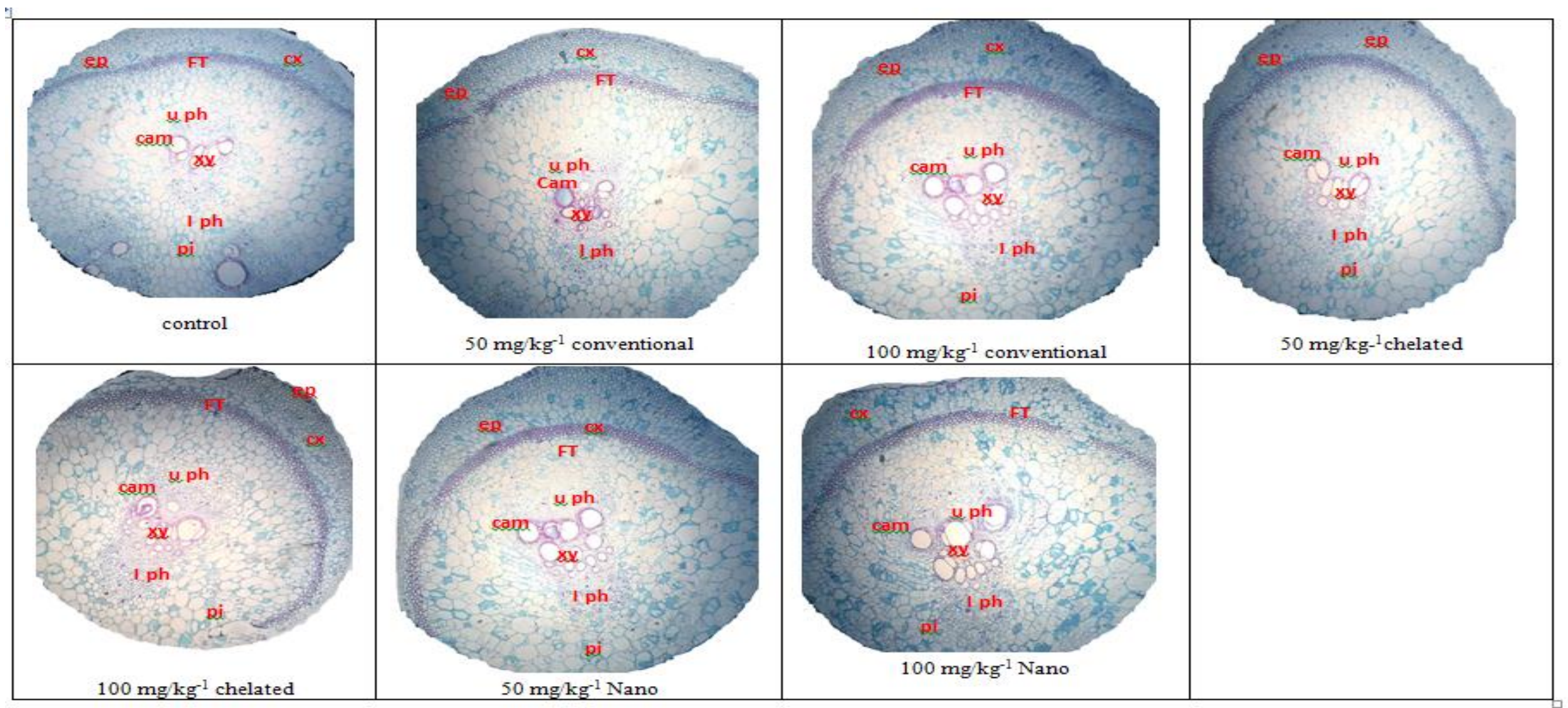

Fig. (2): Transverse sections $(X=24)$ through $2^{\text {nd }}$ internode of the main stem of cucumber at 30 days after transplanting as affected by the different applied treatments. ep= Epidermis $\quad \mathrm{cx}=$ Cortex $\quad \mathrm{u}$ ph= upperPhloem tissue $\quad \mathrm{I}$ ph= lowerphloem $\quad$ cam=Cambium $\quad \mathrm{xy}=\mathrm{Xylem}$ tissuepi= Pith 


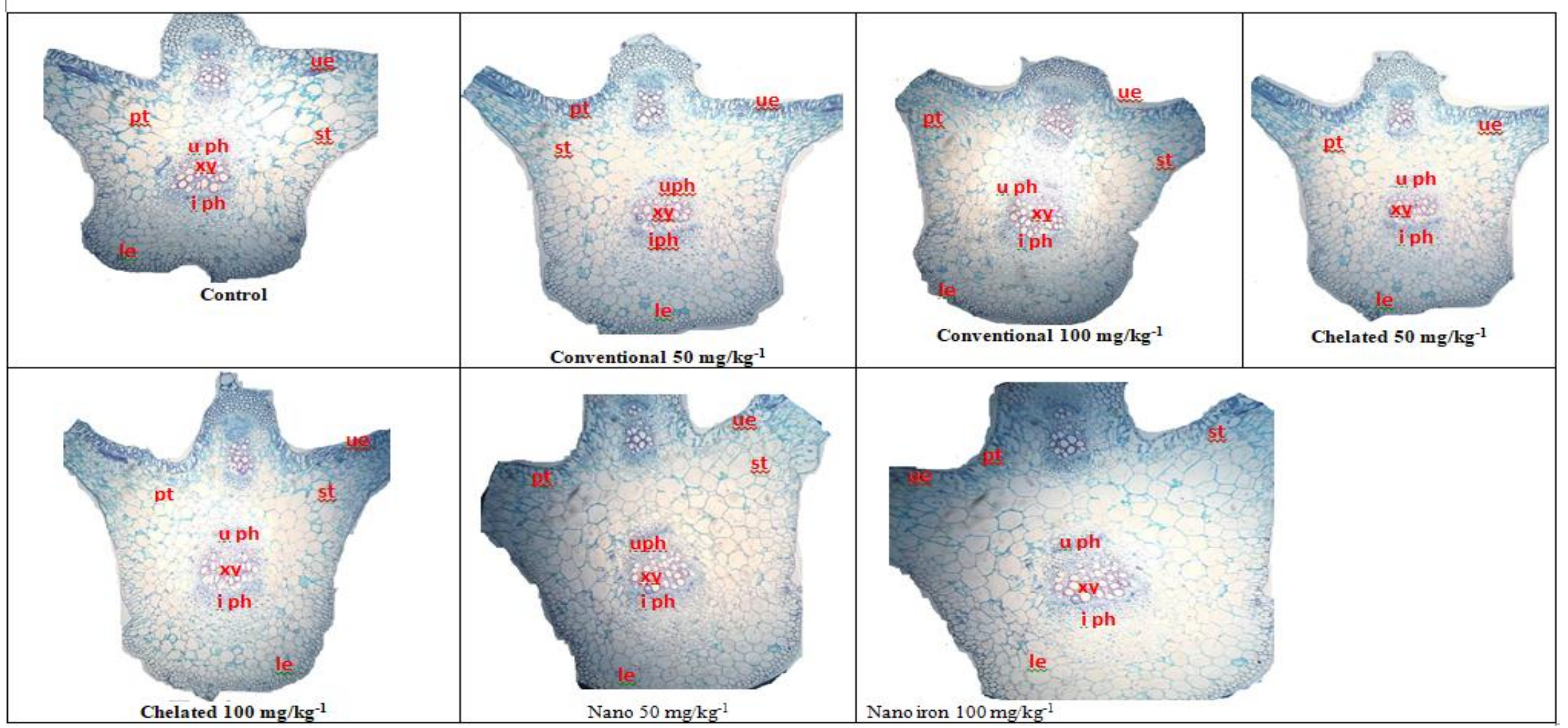

Fig. (3): Transverse sections $(X=24)$ through $2^{\text {nd }}$ apical leaf of cucumber plants at 30 days after transplanting as affected by the different applied treatments. ue= Upper epidermis $p t=$ Palisade tissue $s t=$ Spongy tissue le= Lower epidermis u ph= upper Phloem tissue I ph $=$ lower phloem tissue 
Table 6. Effect of nano, chelated and conventional iron on early yield and yield characteristics of cucumber plants (Cucumas satives L.) during 2015 and 2016 seasons.

\begin{tabular}{|c|c|c|c|c|c|c|c|c|c|}
\hline \multirow{3}{*}{\multicolumn{2}{|c|}{\begin{tabular}{l}
\multicolumn{2}{c}{ Charactractics } \\
Treatments \\
Iron Source $\quad$ Dose $\mathrm{mg} / \mathrm{kg}^{-1}$
\end{tabular}}} & \multirow{2}{*}{\multicolumn{2}{|c|}{ Early Fruit Number./plant }} & \multirow{2}{*}{\multicolumn{2}{|c|}{ Fruit length $(\mathrm{cm})$}} & \multirow{2}{*}{\multicolumn{2}{|c|}{ Fruit Diameter $(\mathrm{cm})$}} & \multirow{2}{*}{\multicolumn{2}{|c|}{ Early Fruit Yield (kg/plant) }} \\
\hline & & & & & & & & & \\
\hline & & \multirow{2}{*}{$\begin{array}{l}\mathbf{1}^{\mathrm{St}} \\
\text { season }\end{array}$} & \multirow{2}{*}{$\begin{array}{l}2^{\text {nd }} \\
\text { season }\end{array}$} & \multirow{2}{*}{$\begin{array}{l}1^{\mathrm{St}} \\
\text { season }\end{array}$} & \multirow{2}{*}{$\begin{array}{l}2^{\text {nd }} \\
\text { season }\end{array}$} & \multirow{2}{*}{$\begin{array}{l}1^{\mathrm{St}} \\
\text { season }\end{array}$} & \multirow{2}{*}{$\begin{array}{l}2^{\text {nd }} \\
\text { Season }\end{array}$} & \multirow{2}{*}{$\begin{array}{l}1^{\mathrm{St}} \\
\text { season }\end{array}$} & \multirow{2}{*}{$\begin{array}{l}\mathbf{2}^{\text {nd }} \\
\text { season }\end{array}$} \\
\hline & & & & & & & & & \\
\hline CONVFe & & $5.00 c^{¥}$ & $3.75 c$ & $27.74 b$ & $25.68 \mathrm{c}$ & $5.58 \mathrm{~b}$ & $5.28 \mathrm{c}$ & $2.66 c$ & $2.27 \mathrm{~b}$ \\
\hline CHELFe & & $8.50 \mathrm{~b}$ & $5.00 \mathrm{~b}$ & $32.74 b$ & $31.88 \mathrm{~b}$ & $6.23 b$ & $6.15 b$ & $3.66 \mathrm{~b}$ & $3.27 \mathrm{~b}$ \\
\hline NANOFe & & $9.50 \mathrm{a}$ & $6.25 a$ & $36.40 \mathrm{a}$ & $38.94 a$ & $7.15 \mathrm{a}$ & $8.39 a$ & $6.16 a$ & $5.82 \mathrm{a}$ \\
\hline 0 & & $8.33 \mathrm{z} €$ & $7.50 \mathrm{y}$ & $28.78 y$ & $28.68 \mathrm{y}$ & $5.00 \mathrm{z}$ & $5.72 \mathrm{z}$ & $3.29 \mathrm{z}$ & $3.15 y$ \\
\hline 50 & & $9.66 y$ & $8.75 y$ & $30.86 y$ & $31.67 \mathrm{y}$ & $7.17 y$ & $7.27 y$ & $4.99 \mathrm{y}$ & $4.66 \mathrm{y}$ \\
\hline \multirow{2}{*}{\multicolumn{2}{|c|}{100}} & $10.66 \mathrm{x}$ & $11.00 \mathrm{x}$ & $34.24 \mathrm{x}$ & $39.85 x$ & $9.15 x$ & $9.12 \mathrm{x}$ & $6.11 x$ & $6.55 x$ \\
\hline & & \multicolumn{2}{|c|}{ Source X Dose } & & & & & & \\
\hline $\begin{array}{l}\text { CONV. } \\
0\end{array}$ & & $3.15^{*}$ & $4.00 *$ & $25.68 *$ & $28.24 *$ & $5.11 *$ & $5.24 *$ & $2.55^{*}$ & $2.66 *$ \\
\hline 50 & & 3.52 & 3.98 & 28.58 & 29.34 & 5.36 & 5.74 & 3.15 & 3.85 \\
\hline 100 & & 4.21 & 4.80 & 28.42 & 31.45 & 5.98 & 6.11 & 4.11 & 4.25 \\
\hline $\begin{array}{l}\text { CHEL. } \\
0\end{array}$ & & 4.25 & 4.50 & 30.35 & 30.35 & 5.29 & 5.47 & 3.58 & 3.94 \\
\hline 50 & & 9.50 & 7.50 & 27.89 & 32.97 & 5.88 & 6.97 & 4.36 & 4.66 \\
\hline 100 & & 9.00 & 8.25 & 33.58 & 33.58 & 6.87 & 7.65 & 5.45 & 5.08 \\
\hline $\begin{array}{l}\text { NANO } \\
0 \\
\end{array}$ & & 6.25 & 3.50 & 23.44 & 28.27 & 5.36 & 5.85 & 4.94 & 5.88 \\
\hline 50 & & 10.00 & 11.75 & 38.94 & 41.61 & 8.12 & 8.46 & 7.37 & 6.27 \\
\hline 100 & & 11.50 & 13.75 & 48.11 & 50.57 & 9.19 & 10.25 & 8.51 & 8.34 \\
\hline
\end{tabular}

$¥$ Means separated by same lower case letters in each column is not significantly different among iron sources at $\mathrm{p}<0.05$.

$€$ Means separated by same lower case letters in each column is not significantly different among iron doses at $\mathrm{p}<0.05$.

* indicates significant interaction among iron source $\mathrm{x}$ dose over time at $\mathrm{p}<0.05$. 


\section{Conclusion}

Soil application of nano iron at 50 and $100 \mathrm{mg} / \mathrm{kg}^{-1}$ improved plant growth characteristics, shoot fresh and dry weight, stem and leaves anatomical features, early fruit numbers, fruit length and early fruits yield in cucumber plants (Cucumus sativus) under greenhouse conditions.

\section{References}

Abbas, M.K. (2013).Effect of foliar fertilizer and some growth regulators on vegetative and anatomical characters of dill (Anethumgraveolens L.) Middle-East J.of Sci. Res. 13 (6): 803-811.

Abo-Sedera, F. A.; Shams. A. S.; Mohamed, M. H. M. and Hamoda, A. H. M. (2016). Effect of organic fertilizer and foliar spray with some safety compounds on growth and productivity of snap bean., Annals of Agric. Sci., Moshtohor 54 (1), 105-118.

Abou-Shlell, M. K. (2017).Botanical studies on Moringa plant. M. Sci. of thesis Botany Dept. Fac. Agric. Moshtohor pp 154.

Agamy R.A. (2004). Effect of mineral and/ or biofertilizers on morphological and anatomical characters, chemical constituents and yield of sweet fennel (FoeniculumvulgareMill.Cv.Dulce) plants grown in calcareous soil. Egypt. J. Appli sci., 19 (3): 55-75.

AlirezaLadan, M.; Hesam, V.; Nasim, B. and Narges ,K.(2012).Effect of different Levels of fertilizer nano_Ironchelates on growth and yield characteristics of two Varieties of Spinach (Spinacia oleracea L.): Varamin 88 and Viroflay .Research Journal of Applied Sciences, Engineering and Technology 4(12): 4813-4818, 2012 ISSN: 2040-7467

Bindraban, P. S.; Dimkpa, C.; Nagarajan, L.; Roy, A., and Rabbinge R. (2015). Revisiting fertilisers and fertilisation strategies for improved nutrient uptake by plants. Biol. Fertil. Soils 51 897-911.

Brittenham, G.M. (1994). New advances in iron metabolism, iron deficiency and iron overload. Current Opinion in Hematology, 1, 549-556.

Chen, H. D. and Yada, R. (2011). Nanotechnologies in agriculture: new tools for sustainable development. Trends Food Sci. Technol. 22585594.

Cossins, D. (2014) Next generation: nanoparticles augment plant functions. The incorporation of synthetic nanoparticles into plants can enhance photosynthesis and transform leaves into biochemical sensors. The scientist, news \& opinion, March 16.http://www.thescientist.com/?articles. view/articleNo/39440/title/Next-GenerationNanoparticles-Augment-Plant-Functions/

Fraceto, L. F.; Grillo, R.; Medeiros, G. A.; Scognamiglio, V.; Rea, G., and Bartolucci, C. (2016). Nanotechnology in agriculture: which innovation potential does it have? Front. Environ. Sci. 4:20.

Gui, X.; HeX., M. Y. H.; Zhang, P.; Li, Y. and Ding, Y. (2015). Quantifying the distribution of ceria nanoparticles in cucumber roots: the influence of labeling. RSC Adv. 5 4554-4560.

Hochella, M.F.; Lower, S.K.; Maurice, P.A.; Penn, R.L.; Sahai, N.; Sparks, D.L. and Twining, B.S. (2008) .Nanominerals, mineral nanoparticles, and Earth systems.Science. 2008 Mar 21; 319(5870):1631-5.

Jayvanth, K.; Vijay, B. V.M.; Prasad, S.; Mishra, A. and Shukla,P.K. (2017).Effect of Different Concentrations of Iron Oxide and Zinc Oxide Nanoparticles on Growth and Yield of Strawberry (Fragaria $\mathrm{X}$ ananassaDuch) cv. Chandler,Int.J.Curr.Microbiol.App.Sci 6(8): 2440-2445.

Kobayashi, T. and Nishizawa, N.K. (2012). Iron uptake, translocation, and regulation in higher plants.Annu Rev Plant Biol. 2012;63:131-52.

Li, V.N.; Rui, Y.; Gui, X.; Li, X.; Liu, S. and Han, Y.(2014). Uptake, transport, distribution and Bioeffects of $\mathrm{SiO} 2$ nanoparticles in Bt-transgenic cotton. J. Nano biotechnology. Dec 5; (12):50.

Michalet, X.; Pinaud, F.F.; Bentolila, L.A.; Tsay, J.M.; Doose, S.; Li, J.J.; Sundaresan, G.; Gambhir ,S.S. and Weiss, S. (2005).Quantum dots for live cells, in vivo imaging, and diagnostics.Science. 2005 Jan 28; 307(5709):538-44.

Miller, G.W.; Huang, I.J.; Welkie, G.W. and Pushmik, J.C. (1995). Function of iron in plants with special emphasis on chloroplasts and photosynthetic activity. In: Abadia, J., (Ed.), Iron nutrition in soils and Plants. Kluwer Academic Publishers, Dordecht, pp.19-28.

Mimmo, T. D.; Buono D.; Terzano R.; Tomasi N.; Vigani G. and Crecchio R.,. (2014). Rhizospheric organic compounds in the soil-microorganismplant system: their role in iron availability. Eur. J. Soil Sci. 65 629-642.perspective. Trends Food Sci. Technol. 17 547-556.

Mohamed, A.; Sadegh, A. and Saaeid, M. ( 2014) Effect of time and concentration of nano-Fe foliar application on yield and yield components of wheat.Int.J. Of Biosicnce, (IJB) Vol4, (9):69-75.

Mohsen, K. (2013). Effect of Foliar Application of Iron and Zinc on Growth and Productivity of Cucumber., Bull. Env. Pharmacol. Life Sci., Vol 2 (11): 11-14.

Nassar, M. A. and El-Sahhar, K. F. (1998).Botanical preparations and microscopy (Microtechnique). Academic Bookshop, Dokki, Giza, Egypt, pp: 219 (In Arabic).

Sánchez-Alcalá, I.; delcampillo, M. D.; Barrón V. and Torrent J. (2014). Evaluation of preflooding effects on iron extractability and phytoavailability in highly calcareous soil in containers. Plant Nutr. Soil Sci. 177 150-158. 
Sanguansri, P. and Augustin, M. A. (2006). Nanoscale materials development-a foodindustry.Plant growth nutrition. 13 114-125.

Sastry, R. K.; Rao, N. H.; Cahoon, R. and Tucker, K. (2007). "Can nanotechnology provide the innovations for a second green revolution in Indian agriculture," in Proceedings of the Nanoscale Science and Engineering Grantees Conference, Arlington, VA.

Sass, J.E. (1951). Botanical microtechnique. Iowa state collage press, Ames, Iowa, pp228.

Shankramma, K, S.; Yallappa, A.D.; Shivanna, M. B. and Manjanna, J. (2016). Fe2O3 magnetic nanoparticles to enhance $S$. lycopersicum (tomato) plant growth and their biomineralization, Applied Nanoscience, Volume 6, pp 983-990.

Vasconcelos, M. W. and Grusak, M. A. (2014). Morpho-physiological parameters affecting iron deficiency chlorosis in soybean (Glycine max L.). Plant Soil 374 161-172.

Sotiropoulos, T.E.; Therios, I.N.; Dimassi, K.N.; Bosabalidis, A. and Kofidis,G. (2002). Natritional status, growth , $\mathrm{Co} 2$ assimilation and leaf anatomical responses in two kiwi fruit species under boron toxicity . J. of plant Nuti., 25 (6):1249-1261.

Ye, Li. L.; Wang, L.; Wang, S.; Li, S.; Duj, Z. S. and Shou, H. (2015).MPK3/MPK6 are involved in iron deficiency-induced ethylene production in Arabidopsis. Front Plant Sci. 6(1):953-956.

Zargar, S. M.; Agrawal, G. K.; Rakwal, R. and Fukao, Y. (2015). Quantitative proteomics reveals role of sugar in decreasing photosynthetic activity due to Fe deficiency. Front. Plant Sci. 6:592

Zuo Y., and Zhang, F. S. (2011). Soil and crop management strategies to prevent iron deficiency in crops. Plant Soil.,339: 83-95. 
